\title{
A Governance Metamodel for Industry 4.0 Service Collaborations
}

DOI:

10.1109/SERVICES.2018.00037

\section{Document Version}

Accepted author manuscript

Link to publication record in Manchester Research Explorer

\section{Citation for published version (APA):}

Kazantsev, N., Sampaio, P., Pishchulov, G., Cisneros Cabrera, S., Liu, Z., \& Mehandjiev, N. (2018). A Governance Metamodel for Industry 4.0 Service Collaborations. In 2018 IEEE World Congress on Services (SERVICES) (pp. 47-48). IEEE. https://doi.org/10.1109/SERVICES.2018.00037

\section{Published in:}

2018 IEEE World Congress on Services (SERVICES)

\section{Citing this paper}

Please note that where the full-text provided on Manchester Research Explorer is the Author Accepted Manuscript or Proof version this may differ from the final Published version. If citing, it is advised that you check and use the publisher's definitive version.

\section{General rights}

Copyright and moral rights for the publications made accessible in the Research Explorer are retained by the authors and/or other copyright owners and it is a condition of accessing publications that users recognise and abide by the legal requirements associated with these rights.

\section{Takedown policy}

If you believe that this document breaches copyright please refer to the University of Manchester's Takedown Procedures [http://man.ac.uk/04Y6Bo] or contact uml.scholarlycommunications@manchester.ac.uk providing relevant details, so we can investigate your claim.

\section{OPEN ACCESS}




\section{A governance metamodel for Industry 4.0 service collaborations}

\author{
Nikolay Kazantsev \\ Alliance Manchester Business \\ School \\ University of Manchester \\ Manchester, UK \\ nikolai.kazantsev@postgrad.man \\ chester.ac.uk
}

\author{
Pedro Sampaio \\ Alliance Manchester Business \\ School \\ University of Manchester \\ Manchester, UK \\ P.Sampaio@manchester.ac.uk
}

\author{
Zixu Liu \\ Alliance Manchester Business \\ School \\ University of Manchester \\ Manchester, UK \\ zixu.liu@manchester.ac.uk
}

\author{
Grigory Pishchulov \\ University of Manchester \\ Manchester, UK \\ St. Petersburg State University, \\ St. Petersburg, Russia \\ grigory.pishchulov@manchester. \\ ac.uk
}

Nikolay Mehandjiev

Alliance Manchester Business School

University of Manchester

Manchester, UK

n.mehandjiev@manchester.ac.uk

\author{
Sonia Cisneros-Cabrera \\ Alliance Manchester Business \\ School \\ University of Manchester \\ Manchester, UK \\ sonia.cisneroscabrera@manchest \\ er.ac.uk
}

\begin{abstract}
In Industry 4.0 scenarios, the presence of formalized and enforced governance rules helps to clarify how core and external contributors should collaborate to co-design and deliver key subsystems of the finished product. This clarity diminishes the time for establishing collaborations and facilitates tasks execution. However, current governance rules are usually more implicit than explicit and often are subject to timeconsuming negotiation before a new collaboration starts. The concept of Industry 4.0 demands higher levels of dynamism; therefore, we present the importance of governance rules in such digital marketplaces. In this short paper, we lay out the foundation for enabling the explicit definition and enforcement of governance rules by proposing a specialized Abstract Syntax Metamodel for specifying governance rules. With such a model, we aim to aid demand-driven production and logistics service collaborations between suppliers towards enabling a quicker and more predictable creation and execution of the tasks involved.
\end{abstract}

Keywords - Governance rules, Smart Manufacturing

\section{INTRODUCTION}

Modern collaborative activities involving suppliers of all sizes along supply chains result in building partnerships driven by manufacturer demand and aimed at cooperative order fulfilment [7]. The movement to Industry 4.0 concept [11] such as "lot size of one" and demand-responsive production means these collaborations would be formed "on the fly" to respond to the needs of a fast changing market with shorter product lifecycles. A promising approach to pursue this concept is establishing collaborative marketplaces [3] where demand from manufacturers could be matched with capabilities and capacities of available suppliers, thus accelerating formation of a supplier collaboration that is able to bid for larger business opportunities [5] and reducing supplier switching costs to such formations [7]. Current information technologies can support such demand-driven collaborations (DDC) between suppliers, yet the uptake of this approach is impeded by a number of factors [7], one of them being lack of formalization and enforcement of governance rules, which results in high switching costs to such partnerships. To significantly reduce the burden of setting up collaborative networks and shorten the time to jointly respond to business opportunities we aim such rules to be enabled for all participants of Industry 4.0 scenarios.

The goal of this paper is to present an abstract syntax of governance rules to underpin demand-driven collaborations.

We use Unified Modelling Language (UML) [1, 2] to create a metamodel that encapsulates collaboration properties, knowledge protection and security rules - in order to shift from ad-hoc case-specific governance rules management to systematic, industry-enforced governance tools for handling production and logistics service partnership formation concerns. This will lay a foundation for a domain specific language (DSL) [4] for Industry 4.0 to increase the speed of DDC formation [9]. We build on the results of the DIGICOR project (https:// www.digicor-project.eu/) that aims at developing a collaboration platform, tools, and services for the setup and coordination of aerospace production networks.

\section{GOVERNANCE RULES IN THE AEROSPACE INDISTRY}

Original Equipment Manufacturers (OEMs) commonly collaborate with hundreds of tier-1 suppliers that handle transactions with multiple SME clusters. Taking into account the presence of sensitive operational data and different attitudes of suppliers to information privacy, we propose a DSL to provide specialised constructs and to explicitly specify governance rules that facilitate demanddriven collaborations and encourage suppliers to join production networks. Table 1 exemplifies three governance rules identified by an aerospace OEM to support interaction with supplier clusters. In the table, the notion of a meta-rule refers to an abstract rule template conceivable for different governance modes; it needs to be instantiated for a specific mode (called collaboration regime). 
TABLE I. EXAMPLE OF GOVERNANCE RULES (EXCERPT)

\begin{tabular}{|c|l|c|c|}
\hline $\begin{array}{c}\text { Meta- } \\
\text { rule }\end{array}$ & \multicolumn{1}{|c|}{ Instantiation of the meta-rule } & $\begin{array}{c}\text { Instruction or } \\
\text { constraint? }\end{array}$ & $\begin{array}{c}\text { Priority } \\
\text { for DDC }\end{array}$ \\
\hline 1 & $\begin{array}{l}\text { The partners of a DDC act autonomously } \\
\text { regarding legal and economic decisions, but } \\
\text { have to come to an agreement regarding the } \\
\text { decisions in the name of the DDC. }\end{array}$ & Instruction & High \\
\hline 2 & Every partner company has one vote. & Constraint & High \\
\hline 3 & $\begin{array}{l}\text { Decisions in the meeting of members have } \\
\text { to be recorded, subscribed from auditor and } \\
\text { made accessible for all partners. }\end{array}$ & Instruction & Medium \\
\hline
\end{tabular}

\section{METAMODEL DESCRIPTION}

The abstract syntax metamodel restricts the possible structure of collaboration to demand-driven partnerships initiated by the new order (Fig. 1). The model defines the main concepts of a Domain Specific Language, their relationships and includes formalisation of rules (Table 1) $[8,6]$.

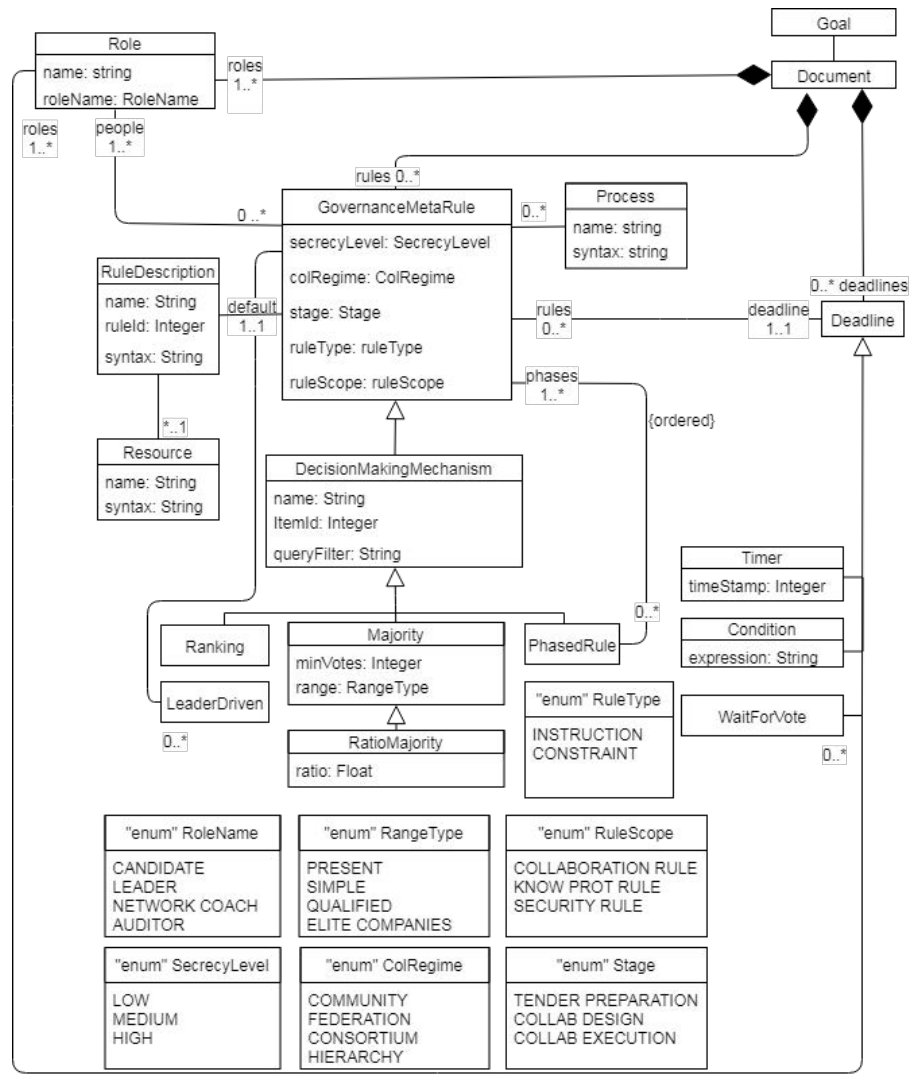

Fig. 1. Abstract syntax of a metamodel [6] to represent governance rules for demand-driven collaborations

The top-level construct in the model is the meta class Document (linked with a collaboration Goal) that includes: a group of supplier roles (Role), rules (GovernanceMetaRule) and deadlines (Deadline). A Role represents any supplier who participates in decision-making (candidate, leader, network coach, and auditor). A governance rule may involve decision making tasks represented in the DecisionMakingMechanism class, which also specifies whether a rule is either an additional instruction or process constraint (ruleType) and if it is related to knowledge protection, collaboration or security (ruleScope). The actual stage of partnership is encapsulated into Stage that could be either a (1) tender preparation, (2) collaborative design or (3) task execution. GovernanceMetarules are linked with Resource and Process classes. They could be applied to a particular secrecy level (appliedTo SecrecyLevel) and collaboration regime: community, federation, consortium or hierarchy (colRegime) [10]. The scope of the rule can also be defined (queryFilter attribute) [5] (e.g., high/low priority). Several types of decision rules are predefined: simple majority, qualified majority, or privileged company's choice. E.g. under simple majority rule (Majority metaclass), to commit a decision, it needs to be supported by over $50 \%$ of votes. When a supplier accepts or declines the proposed collaboration, it takes an active position in decision-making that is implemented into LeaderDriven metaclass.

The developed metamodel is applicable to enforce the governance rules for OEMs and their suppliers.

\section{FUTURE WORK}

This paper describes the first step of development of DSL for Industry 4.0. The next steps include the development of a specific syntax and semantics of DSL, its implementation on a compiler, and its validation in OEM supply chain.

\section{REFERENCES}

[1] G. Booch, "UML in action". Communications of the ACM, vol. 42(10), 1999, pp. 26-28.

[2] M. Brambilla, J. Cabot, M. Wimmer, "Model-Driven Software Engineering in Practice". Morgan \& Claypool Publishers, 2012.

[3] S. Cisneros-Cabrera, A. Ramzan, P. Sampaio, N. Mehandjiev, "Digital Marketplaces for Industry 4.0: A Survey and Gap Analysis", In Working Conference on Virtual Enterprises, Cham: Springer, 2017, pp. 18-27.

[4] M. Fowler, "Domain-specific languages". Addison-Wesley, 2011.

[5] P. Grefen, N. Mehandjiev, G. Kouvas, G. Weichhart, R. Eshuis, "Dynamic business network process management in instant virtual enterprises," Computers in Industry, vol. 60(2), 2009, pp. 86-103.

[6] C. Izquierdo, J. Luis, J. Cabot. "Enabling the definition and enforcement of governance rules in open source systems". In: Proceedings of the 37th International Conference on Software Engineering. Volume 2, IEEE Press, 2015, pp. 505-514.

[7] N. Kazantsev, G. Pishchulov, N. Mehandjiev, P. Sampaio. "Formation of Demand-Driven Collaborations between Suppliers in Industry 4.0 Production Networks". In: R.W. Grubbström, H.H. Hinterhuber, J. Lundquist (Eds.) PrePrints, $20^{\text {th }}$ International Working Seminar on Production Economics, Innsbruck, February, 2018, pp. 255-266.

[8] A. Kleppe, "Software Language Engineering: Creating Domain-Specific Languages Using Metamodels". Addison Wesley, 2008.

[9] N. Mehandjiev, A. Haemmerle, P. Grefen, S. Ristol, "Towards New Frontiers: CrossWork". In: N. Mehandjiev, P. Grefen, (Eds.) Dynamic Business Process Formation for Instant Virtual Enterprises. London: Springer, 2010, pp. 13-23.

[10] S.D. Pathak, Z. Wub, D. Johnston, "Toward a structural view of coopetition in supply networks". Journal of Operations Management, vol. 32(5), 2014, pp. 254-267.

[11] J. Smit, S. Kreutzer, C. Moeller, M. Carlberg, "Industry 4.0". European Parliament, 2016, Document No. IP/A/ITRE/2015-02.
This work was supported by the European Commission under the European Union's Horizon 2020 research and innovation programme (grant agreement $\mathrm{n}^{\circ} 723336$ ). 